\title{
PARAMETRIC ANALYSIS OF HYDRODYNAMIC FORCES DURING BERTHING OPERATIONS
}

\section{ANALIZA PARAMETRYCZNA SIL HYDRODYNAMICZNYCH PODCZAS OPERACJI CUMOWANIA STATKU}

\section{Teresa ABRAMOWICZ-GERIGK}

\author{
Gdynia Maritime University, Faculty of Navigation \\ Akademia Morska w Gdyni, Wydział Nawigacyjny \\ Al. Jana Pawla II 3 \\ 81-345 Gdynia, Poland \\ E-mail: tagerigk@am.gdynia.pl
}

\begin{abstract}
Prediction of hydrodynamic forces induced during self-berthing is the most important problem in modelling ship - berth interactions. The paper presents the parametric analysis of these forces, performed using the results of open water model tests and proposed regression models. The study allowed to quantify the importance of examined parameters, necessary in the development of the completed model of interaction forces with aim of its further application in the simulation model of ship manoeuvring motions.
\end{abstract}

Keywords: hydrodynamic forces, modelling, ship berthing.

Streszczenie: Przewidywanie sił hydrodynamicznych powstających podczas samodzielnego cumowania statku stanowi najistotniejszy problem podczas modelowania sił oddziaływania statek - nabrzeże. W artykule przedstawiono analizę parametryczną tych sił w oparciu o wyniki badań modelowych oraz zaproponowane modele regresyjne. Przeprowadzone badania pozwoliły określić istotność badanych parametrów, potrzebną przy opracowaniu całościowego modelu sił oddziaływania statek-nabrzeże i jego aplikacji w modelu symulacji ruchu statku.

Słowa kluczowe: siły hydrodynamiczne, modelowanie, cumowanie. 


\section{Introduction}

Berthing manoeuvres are the most difficult, time consuming and dangerous harbour operations. Following the inadequate manoeuvres, frequently injuries of crew members and structural damages of vessels are caused. To safely and efficiently berth big vessels the information about the local conditions in relation to the vessel and its motion is required. This must include the position of other berthed vessels and the fendering systems. To have a complex safety measure it is necessary to predict wind, waves, sea current and restricted waters effects. Simulation of ship motion is now the best tool used in design, training and operation. There are several mathematical models of ship manoeuvring motions which are generally accepted, however there are no reliable models which can simulate ship motions at slow speed and restricted waters conditions.

The rough models are successfully used in full mission simulators and preliminary studies. The need for accurate models is related to the development of different aids to navigation especially for self - manoeuvring ferries (ro-ro and ro-pax vessels), due to the development of short-sea shipping and the introduction of MOS (Motorways of the Sea) in Europe.

Similar to the aircraft industry where amount and requirements of traffic caused the transformation from pure manual to fully automated operation, the congestion of vessel traffic leads to the implementation of automatic navigation systems. The concept of an automatic berthing system which provides the necessary information on position, velocity, attitude (roll, pitch, and heading) concerns many aspects such as integration of sensors, personnel training, port infrastructure and mathematical models.

The most widely used modular approach in mathematical modeling of ship manoeuvring motions means that each force and moment acting on the ship can be expressed as the sum of a hull, propeller, rudder and thruster modules based on their effective hydrodynamic characteristics. In the case when the fluid flow around the ship is disturbed by the vicinity of another object a module of the interaction forces is added.

However the model of the additional forces due to the interactions can be formulated on the basis of the model tests, in the case of self-berthing due to the fluid dynamics the simple linear superposition of the component forces induced by the propellers and bow thrusters acting separately can not be applied (AbramowiczGerigk, 2008).

The paper presents the parametric study of the hydrodynamic forces induced during self-berthing. The study has been performed using the results of open water model tests, of 1:16 scale car-passenger ferry model and the regression models of the forces. The study allowed to predict the importance of different parameters, which is necessary in the development of the completed model of interaction forces with aim of their application in the simulation model of ship manoeuvring motions. 


\section{Determination of ship berthing forces in design and operation}

There are several empirical methods, i.a. recommended by PIANC (PIANC, 2002), vendors of fenders and civil engineering codes, which allow to calculate the impact of a berthing vessel.

The berthing energy to be absorbed by the fenders is usually calculated by multiplying the vessels total kinetic energy by the berthing coefficient, which is a product of the following elements:

- eccentricity coefficient accounting for ship's rotation,

- berth configuration factor which represents the portion of energy absorbed by the cushion effect of water between the approaching vessel and the quay wall,

- softness factor which represents the portion of energy absorbed by deformation of the fender and ship hull,

- friction coefficient between the fender and ship side,

- mass factor which depends on the momentum transferred from the ship to surrounding water.

There are many simplifications in the empirical approach: the deflection of fenders is not considered for the elastic fenders and big vessels, the effect of piling berth is neglected, mass factor does not account for the water depth to ship draft ratio, type of berth, fender stiffness, berthing velocity and the acceleration / deceleration of the ship. The recent studies (Bradshaw et al., 2006; Okazaki \& Ohtsu, 2006) convince that the more precise calculations are necessary.

The current analytical methods such as the kinetic energy approach do not consider the energy dissipated in the system during vessel impact. Energy dissipation has the effect of reducing the forces on the vessel and fender and therefore should be considered in design to evaluate the relative performance of various types of fendering systems.

The dynamic approach to the analysis of fender piles where the impacting vessel coupled with the fender pile is modeled as a freely vibrating, multi degree of freedom structure with lumped masses, stiffness and damping allows to determine the reduction of the estimated forces on the pile by about $25 \%$ as compared to the kinetic energy method (Bradshaw et al., 2006).

The lateral added mass of the ship moving laterally toward a quay, because of the existence of the quay, alters the portion of potential flow component of the hydrodynamic lateral force, caused by the lateral acceleration. The other portion of this component, generated by lateral velocity depends on the rate of change in the added mass. The viscous drag force varies with velocity, the cross flow drag coefficient under conditions of accelerating motion is about $10 \%$ greater than under constant speed motion.

The lateral added mass affected by the quay is from 2 to 4 times the added mass in open water, at the distances between the quay and the ship in the range less than 0.1 of the ship breadth.

Recently, minimum time berthing problems have been numerically solved 
(Okazaki et al. 2006), using neural network controllers, however despite of use of the neural network to improve the model, the detailed ship motion models are necessary to obtain the optimal solution.

In general efforts to model the hydrodynamic forces during self berthing were not successful (Shin \& Lee, 2004; Yoo et al., 2006). Recommendations are given for further tests to assist in defining vessel maneuverability in a variety of berthing situations.

\section{Prediction of hydrodynamic forces during berthing manoeuvres of self-berthing vessels}

To recognise the influence of the distance between the ship and berth, as well as water depth to draft ratio on the performance of propellers working in push-pull mode with different rudder angles and different settings of the bow thrusters, the set of model tests has been carried out within the project sponsored by Ministry of Science and Higher Education: "The influence of berth type and water depth on the efficiency of steering devices and propellers during berthing and unberthing".
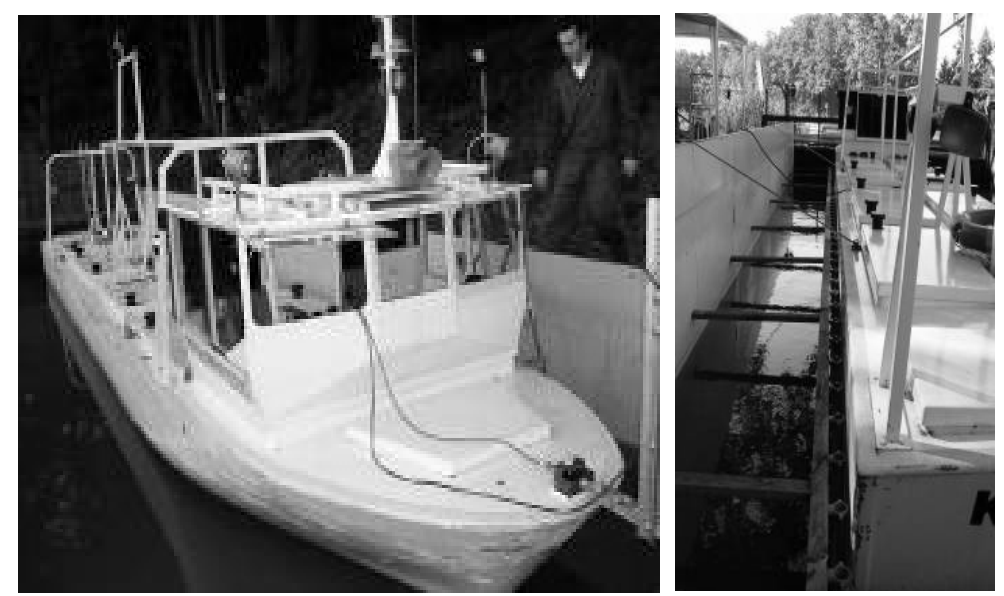

Fig. 1. Experimental setup: berth models - tight wall and piles.

The project was carried out at Gdynia Maritime University. The execution of a systematic experimental program for the stationary model allowed to study a big number of parameters influencing the interaction forces.

The investigated relationship between the parameters and their influence on the interaction forces allowed for the development of the regression models of hydrodynamic forces. The non-dimensional surge force, sway force and yawing moment have been defined in coordinate system related to the ship (figure 2) equation (1), (2) and (3). 


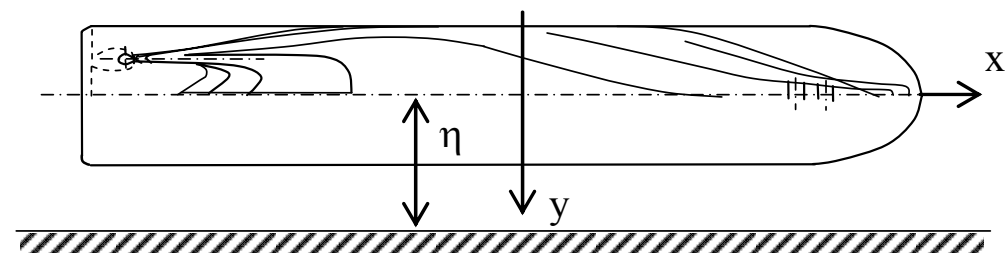

Fig. 2. Coordinate system.

$$
\begin{gathered}
\mathrm{Fx}^{\prime}=\frac{\mathrm{Fx}}{0.5 \rho \mathrm{gL}^{2} \mathrm{~T}} \\
\mathrm{Fy}^{\prime}=\frac{\mathrm{Fy}}{0.5 \rho g \mathrm{~L}^{2} \mathrm{~T}} \\
\mathrm{Mz}^{\prime}=\frac{\mathrm{Mz}}{0.5 \rho g \mathrm{LL}^{3} \mathrm{~T}}
\end{gathered}
$$

where:

Fx - surge force,

Fy - sway force,

$\mathrm{Mz}$ - yawing moment,

$\rho$ - water density,

g - acceleration of gravity,

L - model length between perpendiculars,

$\mathrm{T}$ - model draft.

The non-dimensional model-berth distance $\mathrm{b}$ is defined as follows:

$$
\mathrm{b}=\frac{\eta}{\mathrm{B}}
$$

where:

B - model breadth,

$\eta \quad$ - distance from the berth to the model centre line. 
The main parameters of the model are presented in Table 1.

Table 1. Main particulars of the ferry model.

\begin{tabular}{|l|l|}
\hline Length over all & $10.98 \mathrm{~m}$ \\
\hline Length between perpendiculars & $9.64 \mathrm{~m}$ \\
\hline Breadth & $1.78 \mathrm{~m}$ \\
\hline Draft & $0.42 \mathrm{~m}$ \\
\hline Displacement & $4.89 \mathrm{~m} 3$ \\
\hline Block coefficient & 0.687 \\
\hline Model scale & $1: 16$ \\
\hline
\end{tabular}

The multidimensional model of the hydrodynamic forces for ship berthing and unberthing was developed in form of equation (5) using multidimensional regression and correlation analyses. The different model coefficients were obtained for the case of ship approaching and leaving the quay. The coupled rudder settings and the push pull mode of the propellers were assumed.

$$
\begin{aligned}
& F^{\prime}=\alpha_{x_{1}} b+\alpha_{x_{2}} b^{-1}+\alpha_{x_{3}} \psi+\alpha_{x_{4}} \mathrm{Tp}+\alpha_{x_{5}} \mathrm{BT}+\alpha_{x_{6}} \mathrm{~h}+\alpha_{x_{7}} \delta \\
& \mathrm{Fy}^{\prime}=\alpha_{\mathrm{y}_{1}} \mathrm{~b}+\alpha_{\mathrm{y}_{2}} \mathrm{~b}^{-1}+\alpha_{\mathrm{y}_{3}} \psi+\alpha_{\mathrm{y}_{4}} \mathrm{Tp}+\alpha_{\mathrm{y}_{5}} \mathrm{BT}+\alpha_{\mathrm{y}_{6}} \mathrm{~h}+\alpha_{\mathrm{y}_{7}} \delta \\
& \mathrm{Mz}^{\prime}=\alpha_{\mathrm{z} 1} \mathrm{~b}+\alpha_{\mathrm{z}_{2}} \mathrm{~b}^{-1}+\alpha_{\mathrm{z} 3} \psi+\alpha_{\mathrm{z} 4} \mathrm{Tp}+\alpha_{\mathrm{z} 5} \mathrm{BT}+\alpha_{\mathrm{z} 6} \mathrm{~h}+\alpha_{\mathrm{z} 7} \delta
\end{aligned}
$$

where:

$\mathrm{Fx}, \mathrm{Fy}, \mathrm{Mz}$ - surge, sway forces and yawing moment

B - model breadth,

$\psi$ - angle between the model and the berth,

Tp - non-dimensional propellers thrust,

BT - non-dimensional bow thrusters thrust,

$\delta$ - coupled rudders angle,

h - water depth to model draft ratio,

aij - coefficients, $i=x, y, z ; j=1 \ldots 7$. 


\section{Parameters influencing the ship-berth interaction forces}

The investigation of the importance of the influence of particular parameters on the surge, sway forces and yawing moment, expressed in equation (5), has been carried out on the basis of the sensitivity analysis (Gutenbaum, 2003). The sensitivity coefficients are defined as follows (6):

$$
\mathrm{S}_{\mathrm{p}_{\mathrm{i}}}^{\mathrm{Fx}}=\left|\frac{\partial \mathrm{Fx}}{\partial \mathrm{p}_{\mathrm{i}}}\right| \quad \mathrm{S}_{\mathrm{p}_{\mathrm{i}}}^{\mathrm{Fy}}=\left|\frac{\partial \mathrm{Fy}}{\partial \mathrm{p}_{\mathrm{i}}}\right| \quad \mathrm{S}_{\mathrm{p}_{\mathrm{i}}}^{\mathrm{Fz}}=\left|\frac{\partial \mathrm{Mz}}{\partial \mathrm{p}_{\mathrm{i}}}\right|
$$

where:

$\mathrm{p}_{\mathrm{i}}, \mathrm{i}=1 \ldots 6$ - parameters: $\mathrm{b}, \mathrm{h}, \psi, \mathrm{Tp}, \delta, \mathrm{BT}$

The sensitivity coefficients for a particular parameters were calculated for the assumed constant values of other parameters, for example: $h / T=1.2$, propellers settings: Dead Slow Ahead, bow thrusters settings: $50 \%$ and the rudder angles 0 . The results for ship unberthing are presented in Table 2 and figure 3 .

The presented sensitivity coefficient for the distance to the berth $b-$ is the maximum value, for the other parameters the coefficients are constant due to their linear dependence on the forces.
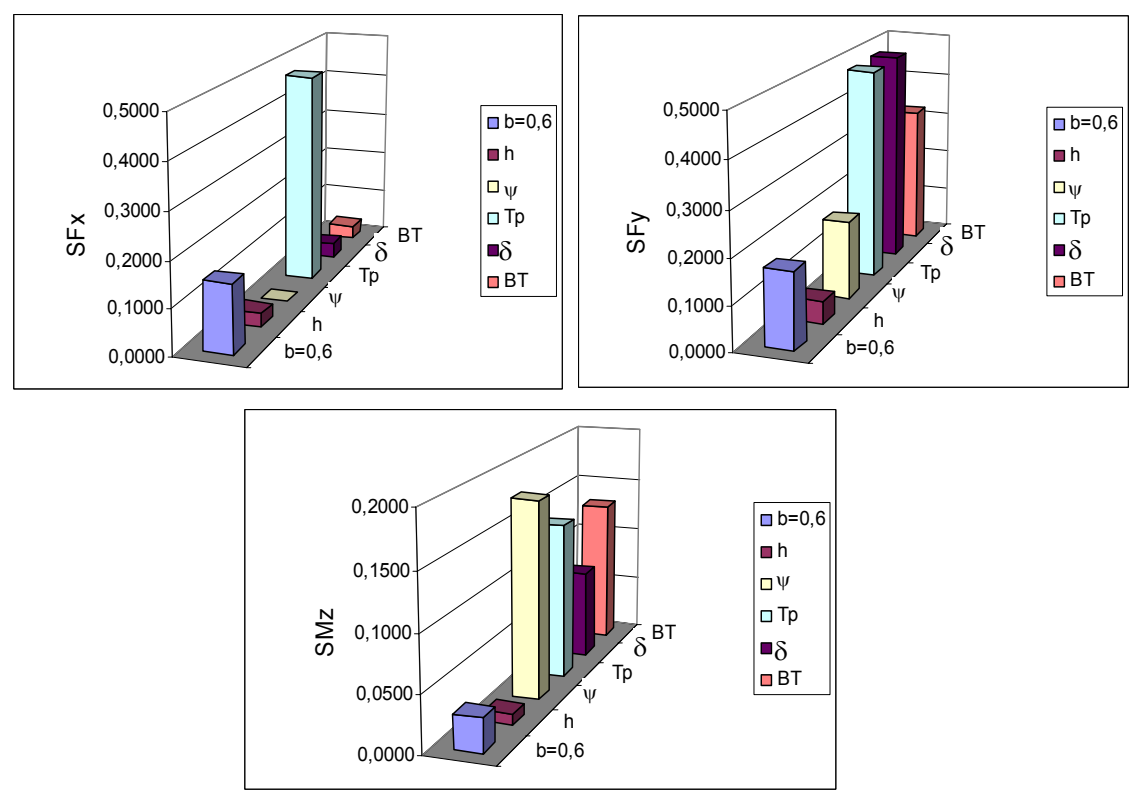

Fig. 3. Sensitivity coefficients for the unberthing case.

Table 2. Sensitivity coefficients. 


\begin{tabular}{|c|c|c|c|c|c|c|}
\hline $\mathrm{p}$ & $\mathrm{b}=0,6$ & $\mathrm{~h}$ & $\psi$ & $\mathrm{Tp}$ & $\delta$ & $\mathrm{BT}$ \\
\hline $\mathrm{S}_{\mathrm{p}}^{\mathrm{Fx}}$ & 0,150 & 0,030 & 0,016 & 0,473 & 0,033 & 0,031 \\
\hline $\mathrm{S}_{\mathrm{p}}^{\mathrm{Fy}}$ & 0,170 & 0,050 & 0,177 & 0,482 & 0,486 & 0,319 \\
\hline $\mathrm{S}_{\mathrm{p}}^{\mathrm{Mz}}$ & 0,030 & 0,010 & 0,061 & 0,141 & 0,080 & 0,131 \\
\hline
\end{tabular}

The surge force is the most sensitive to the changes in the thrust of the propellers and the distance to the berth. The similar influence of these parameters is observed for the sway force. The influence of the rudder angles on the sway force is almost of the same importance and the influence of bow thrusters is only a little less. The sway force model is less sensitive to the changes of water depth to draft ratio, however it reacts on the changes of the angle between the ship and berth much more than the surge force and yawing moment. The yawing moment is the most sensitive to the angle of approach and less sensitive to the changes of water depth to draft ratio.

The influence of the berth type on the sway force and yawing moment is presented in figure 4.
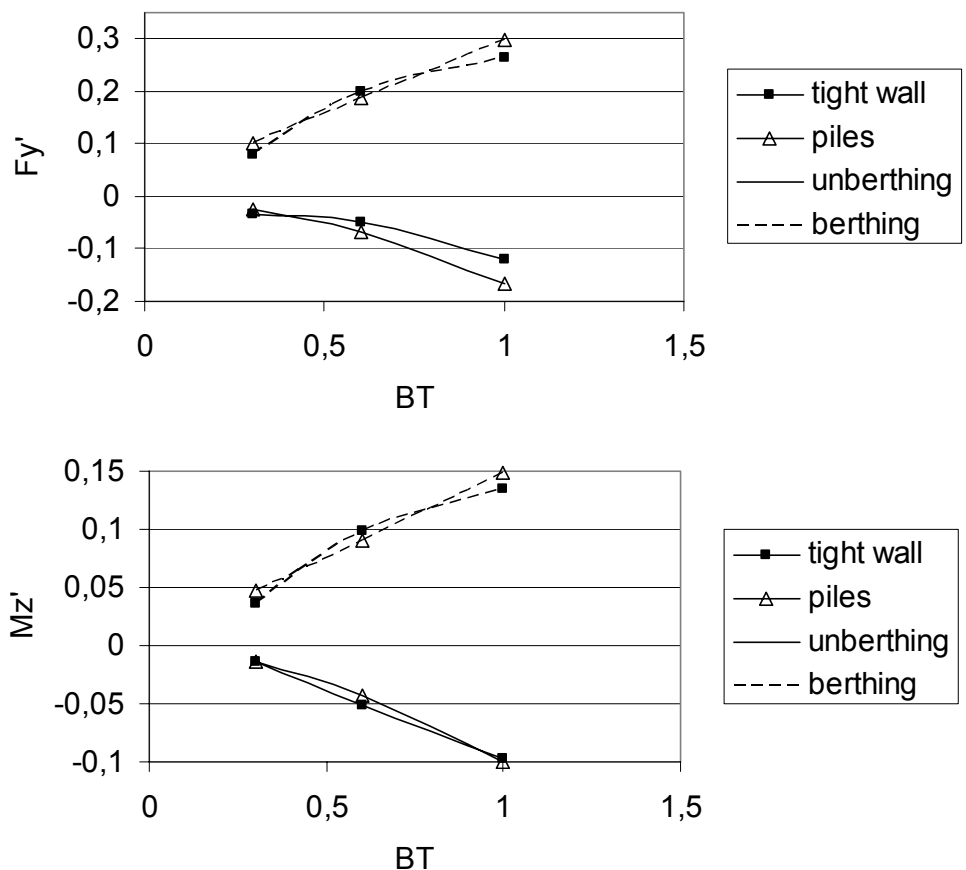

Fig. 4. Sway force and yawing moment generated on the hull by bow thrusters during berthing and unberthing at the tight wall and pile models of the quay.

During the tests the model was positioned at the distance, from the berth equal to 0.1 ship breadth. The piling was positioned at the distance of $1 \mathrm{~m}$ from the tight wall. 
The biggest difference between the sway forces, generated by the bow thrusters, was observed during unberthing for the maximum settings of the bow thrusters. However there is no berth influence on the bow thrusters thrusts, because their outlets are situated close to the model center line (half of ship breadth from the berth), the outflow stream from the bow thrusters reflected from the quay, pushed along the wall in both the stern and bow directions, generated suction force opposite to the repulsion generated by the bow thrusters. The decrease of the repulsion (negative) sway force is $25 \%$ bigger during the unberthing from the tight wall than from the piling.

\section{Conclusions}

The developed regression models of the hydrodynamic forces, generated on the ship hull during unberthing, allowed to determine the influence of the tested parameters on the hydrodynamic forces. The strong effect of the propellers settings on the surge force, sway force and yawing moment was observed. The rudder angle and bow thruster settings are the most important parameters in the sway force model. The model of the yawing moment is the most sensitive to the angle between the ship model and berth. The distance to the quay influences the surge and sway forces about five times more than the yawing moment.

The comparison of the forces generated on the model during berthing and unberthing allowed to observe $25 \%$ bigger decrease of the repulsion force during unberthing from the tight wall than from the piling.

The mathematical model of the hydrodynamic forces induced by a self-berthing vessel is necessary to develop the precise simulation software. The effect of the three-dimensional unsteady flow generated around the vessel is the reason to avoiding simple superposition of the forces generated on the hull by steering and propulsion devices separately, usually used for the open water conditions. The implementation of the correction coefficients does not give good results (Abramowicz-Gerigk, 2008).

However the modeling of the forces is very difficult, the continuous development of piloting and automatic berthing systems as well as Full Mission Simulators used to train the navigators involves further investigations.

The prediction of the influence of external conditions (hydro-meteorological, restricted waters) on the ship performance is one of the most important elements considered with regards to the determination of the risk (Abramowicz-Gerigk, 2007), therefore the main objective should be now the phenomena recognition and quantification following with the model determination.

Acknowledgments: The paper presents a part of results of the research project No. 4T12C01029, sponsored by Polish Ministry of Science and Higher Education. 


\section{References}

1. Abramowicz-Gerigk T.: Safety of berthing manoeuvre. (in Polish) XXXV Zimowa Szkoła Niezawodności, p. 7-12, Szczyrk, 2007.

2. Abramowicz-Gerigk T.: Experimental study on the hydrodynamic forces induced by a twin-propeller ferry during berthing. Ocean Engineering. Elsevier. Volume 35, Issues 3-4, p. 323-332, 2008.

3. Bradshaw A., Baxter C., Tsiatas G., Marinucci A., Ressler J., Morgan R. (2006): Simple Dynamic Model for Fender Pile Analysis and Design. J. Wtrwy., ASCE, Port, Coastal, and Ocean. Engineering, Volume 132, Issue 5, p. 419-422, 2006.

4. Gutenbaum J. Modelowanie matematyczne systemów. Akademicka Oficyna Wydawnicza EXIT. Warszawa 2003.

5. Okazaki T., Ohtsu K. (2006): A Study on Mathematical Maneuvering Model to Solve Minimum Time Approaching Problems. Journal of Japan Institute of Navigation ISSN:03887405, No.114, p. 141-149, 2006.

6. PIANC: Permanent International Association of Navigation Congress Guidelines for the Design of Fender Systems. Brussels, 2002.

7. Shin H., Lee H.(2004): Crabbing Test of $3 \mathrm{~m}$ Ferry Model. Journal of Naval Architects of Korea Vol. 41 No1, February 2004.

8. Yoo W-J., Yoo B.Y.,. Rhee K.P.: An experimental study on the maneuvering characteristics of a twin propeller/twin rudder ship during berthing and unberthing. Ships and Offshore structures Volume: 1, Issue: 3, 2006.

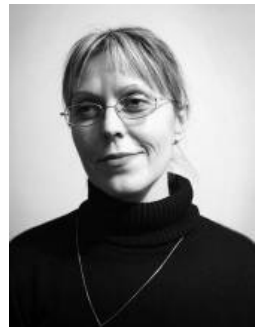

Dr inż. Teresa Abramowicz -Gerigk, Akademia Morska w Gdyni (Gdynia Maritime University, Faculty of Navigation). Specialist in modelling of ship dynamics and safety of maritime transportation. Author or coauthor of more then 30 publications, both in Polish and English. Member of SSRwT KT PAN. Member and coordinator of national R\&D projects. 